UDC 51-76:613.2.038

Doi: 10.31772/2587-6066-2018-19-4-631-636

For citation: Kovalev V. S., Manukovsky N. S., Tikhomirov A. A. [Modeling components of bioregenerative life support system intended for space purposes]. Siberian Journal of Science and Technology. 2018, Vol. 19, No. 4, P. 631-636. Doi: 10.31772/2587-6066-2018-19-4-631-636

Для цитирования: Ковалёв В. С., Мануковский Н. С., Тихомиров А. А. Моделирование компонентов биорегенеративной системы жизнеобеспечения космического назначения // Сибирский журнал науки и технологий. 2018. T. 19, № 4. С. 631-636. Doi: 10.31772/2587-6066-2018-19-4-631-636

\title{
MODELING COMPONENTS OF BIOREGENERATIVE LIFE SUPPORT SYSTEM INTENDED FOR SPACE PURPOSES
}

\author{
V. S. Kovalev ${ }^{2}$, N. S. Manukovsky ${ }^{1,2}$, A. A. Tikhomirov ${ }^{1,2}$ \\ ${ }^{1}$ Reshetnev Siberian State University of Science and Technologies \\ 31, Krasnoyarsky Rabochy Av., Krasnoyarsk, 660037, Russian Federation \\ ${ }^{2}$ Institute of Biophysics SB RAS \\ 50/50, Akademgorodok, Krasnoyarsk, 660036, Russian Federation \\ *E-mail: kovalev49@mail.ru
}

We have developed a linear model for compiling and optimizing food components in a bioregenerative life-support system (BLSS) intended for space purposes in the Excel environment using OpenSolver public add-in with COIN-OR$C B C$ solver.

The independent variables in the model are the masses of ingredients used in dishes. The objective functions of modeling are to minimize the total mass of the daily diet and maximize its antioxidant potential. The daily intakes of nutrients in the menu are limited to NASA standards. The upper and lower limits are also imposed on independent variables and the masses of dishes. We have found the content of nutrients in ingredients in open databases. The menu includes the first course, the second course, snacks, desserts, drinks, bread and water. We have presented an example of a concrete calculation of the daily menu consisting of 12 dishes: fresh-soup, chicken with rice, the roast, sausages, tofu, chickpeas, candied nuts, bread, goat milk, soy milk, cocktail and water. These dishes are prepared using 24 ingredients: table salt, water, wheat grains, rice, quinoa, millet, sweet potato, white potato, carrots, safflower oil, soybeans, chickpeas, lentils, cowpeas, strawberries, tomatoes, onions, garlic, chili pepper, quail, pork, tilapia, goat's milk and sugar. The ingredients being used represent edible biomass of plants and animals that are candidates for inclusion in BLSS. Caloric content of a daily diet is assumed to be equal to $2800 \mathrm{kcal}$. It is shown that food imbalances in the estimated daily menu are caused by a shortage of estimated daily intake of pantothenic acid, and also by an excess of iron, phosphorus and saturated fats. Excess intake of iron and phosphorus may not be critical for the health of the users of BLSS. The minimum weight of the daily menu is $2641 \mathrm{~g}$, and its antioxidant potential can reach 14 mmol Ttroloxequivalent.

Keywords: variables, objective function, ingredient, dish, nutrient.

\section{МОДЕЛИРОВАНИЕ КОМПОНЕНТОВ БИОРЕГЕНЕРАТИВНОЙ СИСТЕМЫ ЖИЗНЕОБЕСПЕЧЕНИЯ КОСМИЧЕСКОГО НАЗНАЧЕНИЯ}

\author{
В. С. Ковалёв ${ }^{2 *}$, Н. С. Мануковский ${ }^{1,2}$, А. А. Тихомиров ${ }^{1,2}$ \\ ${ }^{1}$ Сибирский государственный университет науки и технологий имени академика М. Ф. Решетнева \\ Российская Федерация, 660037, г. Красноярск, просп. им. газ. «Красноярский рабочий», 31 \\ ${ }^{2}$ Институт биофизики СО РАН \\ Российская Федерация, 660036, г. Красноярск, Академгородок, 50/50 \\ *E-mail: kovalev49@mail.ru
}

B среде Excel с использованием решателя COIN-OR-CBC в составе общедоступной надстройки OpenSolver разработана линейная модель для составления и оптимизации пищевого звена биорегенеративной системь жизнеобеспечения (БСЖО), предназначенной для использования в космосе.

Независимыми переменными в модели являются массы источников пищи, используемые в блюдах. Целевыми функциияи моделирования являлись минимизаџия общей массы суточного рациона и максимизация его антиоксидантного потенциала. Суточное потребление нутриентов в составе меню было ограничено стандартами НАСА. Верхние и нижние ограничения накладывали также на независимые переменные и массу блюд. Содер- 
жание нутриентов в источниках пищи находили в открытых базах данных. В схему меню включены первое блюдо, второе блюдо, закуски, десерты, напитки, хлеб и вода. Представлен пример конкретного расчёта суточного меню, состоящего из 12 блюд: уха из тиляпии, иьыпеёнок с рисом, жаркое, колбаски, тофу, нут, козинак, хлеб, молоко козье, молоко соевое, коктейль и вода. Эти блюда были скомпонованы из 24 ингредиентов: поваренной соли, воды, зёрен пшеницьл, риса, лебеды, проса, батата, картофеля, моркови, масла сафлорового, бобов соевых, нута, чечевицы, вигны, земляники, томатов, лука, чеснока, периа чили, перепелятины, свинины, тиляпии, молока козье и сахара. В качестве ингредиентов использовали съедобную биомассу растений и животных, являющихся кандидатами для включения в БСЖО. Калорийность суточного раџиона принята равной 2800 ккал. Показано, что пищевые дисбалансы в расчётном суточном меню обусловлены недостатком расчётного суточного потребления пантотеновой кислоты, а также избытком железа, фосфора и насыщенных жиров. Избыточное потребление железа и фосфора, возможно, не является критическим для здоровья обитателей БСЖО. Минимальная масса суточного меню составила 2641 г, а его антиоксидантный потенщиал может достигать 14 ммоль тролокс-эквивалента.

\section{Ключевые слова: переменные, целевая функция, ингредиенты, блюдо, нутриент.}

Introduction. It is known that a space diet was calculated by the method of one-criterion optimization using AMPL environment [1]. In that study we assigned the masses of dishes as independent variables. The balance of ingredient masses in the dishes remained constant, whereas the use of ingredient masses as independent variables may enhance the efficiency of diet optimization. Minimizing equivalent system mass (ESM) of foods was the objective function of optimization

$$
z=\min \sum_{j \in F} c_{j} m d_{j},
$$

where $c_{j}$ is the "cost" of 1 gram of the $j$-th dish in terms of ESM units; $m d_{j}$ is the mass of the $j$-th dish; $F$ - a set of dishes. Nowadays, ESM calculation can be carried out on the basis of terrestrial test-beds [2]. In space conditions, the results of the calculation may not be relevant. Therefore, as an objective function, it is advisable to use the minimization of the daily food mass. This objective function is a variant of ESM minimizing, if in the equation (1) the coefficients $c_{j}=1$.

Space radiation induces oxidative stress in cosmonauts' bodies after a long space flight on the International Space Station $[3 ; 4]$. Partial solution to the problem of oxidative stress is in the selection of ingredients that have antioxidant properties. Dietary countermeasures are food products and preparations that, when ingested into a cosmonaut's body, may have the potential to reduce the effects of ionizing radiation [5]. It is of interest to calculate the antioxidant potential of a diet.

The purpose of this work was to develop a computer model using masses of dish ingredients as independent variables for minimizing the daily food mass consumed in BLSS and maximizing food's antioxidant potential.

Selecting dish ingredients. When compiling the list of ingredients for diet modeling, the following conditions were met: a) data on the biochemical composition of the ingredients should be publicly available; b) the ingredients were used previously in experimental or theoretical studies of BLSS. Ingredients obtained from plants [6] partially meet these conditions; these ingredients are: wheat, rice, oats, quinoa, millet, sweet potato, potatoes, beets, lettuce, carrots, oyster mushrooms, Pinto beans, soybeans, chickpeas, lentils, cow peas, strawberries, tomatoes, cantaloupe, onions, garlic and chili.
To fulfill the norm of the content of animal protein in the diet for cosmonauts [7], we also added to our list the ingredients of animal origin that were considered as candidates for cultivation in BLSS: quail meat [8], quail eggs and pork [9], tilapia [10], milk [11], as well as table salt, water, sugar and safflower oil. Thus, the list of ingredients included 31 names.

Model Description. We conducted simulations in the Excel environment using the COIN-OR-CBC solver in the OpenSolver add-in [12]. We used the following objective functions: minimizing the daily food mass and maximizing its antioxidant activity. We assigned the masses of dish ingredients as independent variables. We considered the daily food mass as sum of dish masses. Our linear model was based on the matrix $A$ :

$$
A=\left(\begin{array}{cccccc}
x_{11} & x_{12} & \cdots & x_{1 j} & \cdots & x_{1 v} \\
x_{21} & x_{22} & \cdots & x_{2 j} & \cdots & x_{2 v} \\
\vdots & \vdots & \vdots & \vdots & \vdots & \vdots \\
x_{i 1} & x_{i 2} & \cdots & x_{i j} & \cdots & x_{i v} \\
\vdots & \vdots & \vdots & \vdots & \vdots & \vdots \\
x_{u 1} & x_{u 2} & \cdots & x_{u j} & \cdots & x_{u v}
\end{array}\right),
$$

where $u$ is the number of dish ingredients in the dishes; $v$ - number of dishes in the daily diet; $x_{i j}$ - mass of $i$-th ingredient in the $j$-th dish.

The rows in the matrix $A$ represented the distribution of dish ingredients along the dishes and the columns represented the masses of dish ingredients in the dishes.

The total masses of ingredients in the daily menu were represented by a column vector:

$$
\overrightarrow{V T M}=\left[\begin{array}{llllll}
X_{1} & X_{2} & \cdots & X_{i} & \cdots & X_{u}
\end{array}\right]^{\prime},
$$

where $X_{i}=\sum_{j=1}^{v} x_{i j}-$ mass of $i$-th ingredient in the daily diet.

We calculated the mass of the $j$-th dish using the following formula:

$$
m d_{j}=\sum_{i=1}^{u} x_{i j} .
$$

We represented the content of nutrients per $100 \mathrm{~g}$ of ingredients as a matrix $B$ : 


$$
B=\left(\begin{array}{cccccc}
n_{11} & n_{12} & \cdots & n_{1 j} & \cdots & n_{1 p} \\
n_{21} & n_{22} & \cdots & n_{2 j} & \cdots & n_{2 p} \\
\vdots & \vdots & \vdots & \vdots & \vdots & \vdots \\
n_{i 1} & n_{i 2} & \cdots & n_{i j} & \cdots & n_{i p} \\
\vdots & \vdots & \vdots & \vdots & \vdots & \vdots \\
n_{u 1} & n_{u 2} & \cdots & n_{u j} & \cdots & n_{u p}
\end{array}\right)
$$

where $p$ is the number of monitored nutrients; $u$ is the number of ingredients in the dishes.

The rows in matrix $B$ represented the nutrient content of the ingredients, and the columns showed the nutrient distribution along ingredients. Data on the content of nutrients in $100 \mathrm{~g}$ of ingredients was taken from open databases [13-15].

We recorded the distribution of the $j$-th nutrient along ingredients as a column vector:

$$
\overrightarrow{N_{j}}=\left[\begin{array}{llllll}
n_{j 1} & n_{j 2} & \cdots & n_{j i} & \cdots & n_{j u}
\end{array}\right]^{\prime} .
$$

We calculated the mass of the $j$-th nutrient in the daily menu as the scalar product of the vectors:

$$
m n_{j}=\overrightarrow{N_{j}} \times \overrightarrow{V T M} / 100 .
$$

We carried out the minimization of the daily food mass using the formula:

$$
T M=\min \sum_{j=1}^{v} m d_{j} .
$$

To maximize the antioxidant potential of the daily food mass, the following formula was used:

$$
A P=\max \sum_{i=1}^{u} a_{i} X_{i} /(100 \times 1000),
$$

where $A P$ - antioxidant potential of the daily food mass, expressed in mmol Trolox-equivalent; $a_{i}-$ antioxidant efficacy, expressed in $\mu \mathrm{mol}$ Trolox-equivalent [16] per $100 \mathrm{~g}$ of $i$-th ingredient [17].

Planning the daily menu: an example. We planned four meals that included soup, main courses, snacks, dessert, bread and drinks. We arranged the dishes according to the plan (tab. 1).

We chose a list of dishes and the composition of the ingredients in the dishes, taking into account the fact that

\begin{tabular}{|c|c|c|c|}
\hline \multicolumn{4}{|c|}{ Meals } \\
\hline 1 & 2 & 3 & 4 \\
\hline Main course & Snack & First course & Snack \\
\hline Bread & Drink & Main course & Drink \\
\hline \multirow[t]{4}{*}{ Drink } & & Snack & \\
\hline & & Dessert & \\
\hline & & Bread & \\
\hline & & Drink & \\
\hline
\end{tabular}
the ingredients were included in the list given in the section "Selecting dish ingredients". The specificity of the menu plan (tab. 1) is shown in tab. 2 .

Table 1
Table 2

Specific menu plan

\begin{tabular}{|lccc|}
\hline \multicolumn{4}{|c|}{ Eating } \\
\hline 1 & 2 & 3 & 4 \\
\hline $\begin{array}{l}\text { Chicken } \\
\text { with rice }\end{array}$ & Morning & Fresh-soup & Nut \\
sausages & & \\
Bread & Soy milk & Roast & Goat milk \\
& & Tofu & \\
& & Candied nuts & Bread \\
& & Cocktail & \\
& &
\end{tabular}

Some constraints were imposed on the masses of variables and dishes. The daily intakes of nutrients were restricted by NASA standards [7]. The calorie value of the daily menu was accepted to be $2800 \mathrm{kcal}$ in accordance with the daily energy consumption of the explorer in the BIOS 3 complex [18] and the estimated energy consumption of the lunar base inhabitant [19]. We carried out the calculation of caloric content of the daily menu according to the Atwater formula:

$$
E=4[\text { protein }]+9[\text { fat }]+4[\text { carbohydrate }],
$$

where [protein], [fat], [carbohydrate] - masses of proteins, fats and carbohydrates in the daily menu.

These 12 dishes (tab. 2, 3) include 24 ingredients (tab. 3). The data in tab. 3 were obtained as a result of optimization of the daily menu with the use of minimizing the total mass of the daily diet as an objective function.

The minimum weight of the daily diet was $2641 \mathrm{~g}$, and its maximum antioxidant activity was $14 \mathrm{mmol}$ Trolox equivalent. Currently, the norm on the antioxidant activity of the daily diet is not established [7]. It should be noted that the antioxidant activity of the products is determined in vitro [16], whereas in vivo the properties of the products are likely to vary.

The calculated diet was not balanced for four nutrients: iron, phosphorus, pantothenic acid and saturated fat. The values of daily intake of iron, phosphorus and saturated fats exceeded NASA standards, while the diet was deficient in pantothenic acid.

It is known that excessive intake of iron and its accumulation in the body can provoke cancer and heart disease [20-22]. In this regard, the installation of low iron consumption seems justified. Nevertheless, the range of both Russian and American products used on board the ISS to complete joint diets did not allow to maintain a low daily iron intake rate $(8-10 \mathrm{mg})$ in accordance with the desire of the American side. In Russian-American joint diets actually used in the $1 \mathrm{st}-7$ th expeditions, iron intake was $21 \mathrm{mg} /$ day. Metabolic parameters did not exceed the limits of permissible physiological fluctuations and did not indicate violations of the nutritional status of crew members. The data obtained show that the joint RussianAmerican diets adequately ensured the energy and constructive metabolism of the crew members during the seven long-term expeditions to the ISS and contributed to the maintenance of the operability sufficient to carry out the flight programs [23]. 
Calculated masses of ingredients in dishes and masses of dishes

\begin{tabular}{|c|c|c|c|c|c|c|c|c|c|c|c|c|}
\hline \multirow[t]{2}{*}{ Ingredients } & \multicolumn{12}{|c|}{ Dishes } \\
\hline & 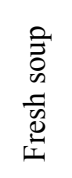 & 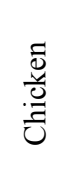 & 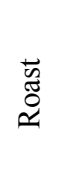 & $\begin{array}{l}\mathscr{心} \\
\mathscr{E} \\
\mathbb{E} \\
\mathscr{E} \\
\tilde{W}\end{array}$ & $\underset{H}{\stackrel{D}{0}}$ & 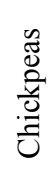 & 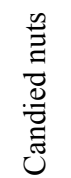 & 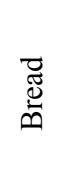 & 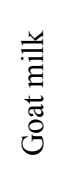 & 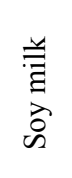 & $\begin{array}{l}\overline{\bar{J}} \\
\bar{U} \\
0 \\
0\end{array}$ & $\frac{\bar{\Phi}}{\stackrel{\vec{\omega}}{3}}$ \\
\hline Table salt & 2 & 0,1 & 0,1 & 0,1 & 0,1 & 0,1 & 0 & 0,1 & 0 & 0 & 0 & 0 \\
\hline Water & 238 & 20 & 40 & 30 & 200 & 30 & 0 & 0 & 0 & 241 & 100 & 100 \\
\hline Wheat grains & 0 & 0 & 0 & 0 & 0 & 0 & 0 & 218 & 0 & 0 & 0 & 0 \\
\hline Rice & 0 & 40 & 0 & 0 & 0 & 0 & 100 & 0 & 0 & 0 & 0 & 0 \\
\hline Quinoa & 0 & 5 & 5 & 5 & 0 & 0 & 0 & 0 & 0 & 0 & 0 & 0 \\
\hline Millet & 5 & 0 & 0 & 0 & 0 & 0 & 0 & 0 & 0 & 0 & 0 & 0 \\
\hline Sweet potato & 0 & 50 & 60 & 0 & 0 & 0 & 0 & 0 & 0 & 0 & 0 & 0 \\
\hline White potato & 70 & 0 & 0 & 0 & 0 & 0 & 0 & 0 & 0 & 0 & 0 & 0 \\
\hline Carrot & 0 & 5 & 0 & 0 & 0 & 0 & 0 & 0 & 0 & 0 & 0 & 0 \\
\hline Safflower oil & 3 & 4 & 10 & 18 & 0 & 0 & 0 & 0 & 0 & 0 & 0 & 0 \\
\hline Soybeans & 0 & 5 & 0 & 2 & 17 & 0 & 0 & 0 & 0 & 80 & 0 & 0 \\
\hline Chickpeas & 0 & 0 & 0 & 0 & 0 & 10 & 0 & 0 & 0 & 0 & 0 & 0 \\
\hline Lentils & 5 & 0 & 0 & 0 & 0 & 0 & 0 & 0 & 0 & 0 & 0 & 0 \\
\hline Vigna & 0 & 0 & 5 & 0 & 0 & 0 & 0 & 0 & 0 & 0 & 0 & 0 \\
\hline Strawberries & 0 & 0 & 0 & 0 & 0 & 0 & 0 & 0 & 0 & 0 & 30 & 0 \\
\hline Tomatoes & 0 & 5 & 5 & 0 & 0 & 5 & 0 & 0 & 0 & 0 & 0 & 0 \\
\hline Onion & 10 & 0 & 10 & 0 & 0 & 0 & 0 & 0 & 0 & 0 & 0 & 0 \\
\hline Garlic & 0 & 5 & 0 & 0 & 0 & 0 & 0 & 0 & 0 & 0 & 0 & 0 \\
\hline Chili pepper & 2 & 2 & 2 & 0 & 0 & 0 & 0 & 0 & 0 & 0 & 0 & 0 \\
\hline Quail & 0 & 60 & 0 & 0 & 0 & 0 & 0 & 0 & 0 & 0 & 0 & 0 \\
\hline Pork & 0 & 0 & 5 & 85 & 0 & 0 & 0 & 0 & 0 & 0 & 0 & 0 \\
\hline Tilapia & 65 & 0 & 0 & 0 & 0 & 0 & 0 & 0 & 0 & 0 & 0 & 0 \\
\hline Goat's milk & 0 & 0 & 0 & 0 & 0 & 0 & 0 & 0 & 600 & 0 & 0 & 0 \\
\hline Sugar & 0 & 0 & 0 & 0 & 2 & 5 & 7 & 0 & 0 & 7 & 7 & 0 \\
\hline Masses of dishes, $\mathrm{g}$ & 400 & 201 & 142 & 139 & 219 & 50 & 107 & 218 & 600 & 328 & 137 & 100 \\
\hline
\end{tabular}

Thus, the daily iron intake $(23 \mathrm{mg})$ calculated in this model is probably not critical. If we consider the consumption of iron in relation to its available form, the NASA requirement looks more realistic.

The upper permissible level of daily intake of phosphorus is not established. Therefore, it is likely that the daily consumption of phosphorus calculated in this work (2685 mg against the normative $1800 \mathrm{mg}$ ) can be considered unacceptable after setting an upper limit on the daily intake of phosphorus.

To prevent the excess of phosphorus and saturated fat in the diets, we can recommend the selection of ingredients with the reduced content of these nutrients. Deficiency of pantothenic acid can be overcome through the use of vitamin products and / or vitamin preparations.

Conclusion. We described the algorithm for calculating the daily diet in BLSS intended for space purposes using the masses of ingredients in dishes as independent variables. We simulated the menu in the Excel environment using the public OpenSolver add-in.

The distinctive features of the model are:

- the use of the free-for-all add-in of OpenSolver;

- the ability to vary the masses of components in dishes.

The calculation of the daily diet presented in this study is demonstrative in nature, since it does not take into account the compatibility of ingredients and the taste of the dishes. The prognosis of the antioxidant activity of the daily menu will be of practical significance when the corresponding dietary standard for cosmonauts is determined.

We see the prospects for further investigation of the problem in the development of recipes and the expansion of the variety of dishes intended for the use by cosmo- 
nauts in BLSS, taking into account individual preferences. In addition, the results of the work provide a basis for expanding the diversity of plants species included in the phototrophic link of closed ecosystems and planning studies to assess the tolerance of the cenosis of these plants to environmental factors in such ecosystems.

Acknowledgements. The work was carried out within the framework of the State Program on the subject No. 56.1.4, section VI of the Program of Fundamental Scientific Research of the Russian Academy of Sciences for 2013-2020.

Благодарности. Работа выполнена в рамках Государственной программы по теме № 56.1.4, раздел VI Программы фундаментальных научных исследований Российской академии наук на 2013-2020 годы.

\section{References}

1. Olabi A. A. The optimization of a bioregenerative life support space diet. Dissertation presented to the Faculty of the Graduate School of Cornell University in partial fulfillment of the requirements for the degree of Doctor of Philosophy. 2001.

2. Czupalla M., Horneck G., Blome H. J. The conceptual design of a hybrid life support system based on the evaluation and comparison of terrestrial testbeds. $\mathrm{Ad}$ vances in Space Research. 2005, Vol. 35, P. 1609-1620.

3. Larina I. M., Percy A. J., Yang J., Borchers Ch. H., Nosovsky A. M., Grigoriev A. I., Nikolaev E. N. Protein expression changes caused by spaceflight as measured for 18 Russian cosmonauts. Scientific Reports. 2017, Vol. 7, Article number: 8142.

4. Versari S., Longinotti G., Barenghi L., Maier J. and Bradamante $\mathrm{S}$. The challenging environment on board the International Space Station affects endothelial cell function by triggering oxidative stress through thioredoxin interacting protein over expression: The ESASPHINX experiment. FASEB Journal. 2013, Vol. 27(11), P. 4466-4475.

5. Risk factor of inadequate nutrition. Evidence Report. National Aeronautics and Space Administration. Lyndon B. Johnson Space Center. Houston, Texas, 2015.

6. Salisbury F. B., Clark M. A. Z. Suggestions for crops grown in controlled ecological life-support systems, based on attractive vegetarian diets. Advances in Space Research. 1996, Vol. 18, P. 33-39.

7. Cooper M. Douglas G. and Perchonok M. Developing the NASA food system for long-duration missions. Journal of Food Science. 2011, Vol. 76, No. 2, P. R40-R48.

8. Meleshko G. I., Guryeva T. S., Shepelev Ye. Ya., Abakumova I. A. Quail as a possible object of biological life-support systems of space crews. Acta Veterinaria Brno. 1993, Vol. 62(4), P. 9-15.

9. Nelson M., Pechurkin N. S., Allen J. P., Somova L. A. and Gitelson J. I. Closed ecological systems, space life support and Biospherics. Handbook of Environmental Engineering. 2009, Vol. 10, P. 517-565.

10. Gonzales J. M., Paul Jr., Brown B. Nile tilapia Oreochromis niloticus as a food source in advanced life support systems: Initial considerations. Advances in Space Research. 2006, Vol. 38, P. 1132-1137.
11. Tako Ya., Arai R., Tsuga S., Komatsubara O., Masuda T., Nozoe S. and Nitta K. SEEF: closed ecology experiment facilities. Gravitational and Space Biology. 2010, Vol. 23, P. 13-23.

12. Mason A. J. OpenSolver - an open source add-in to solve linear and integer progammes in Excel. Operations Research Proceedings. 2012, P. 401-406. Eds.: Klatte Diethard, Lüthi Hans-Jakob, Schmedders Karl. Springer Berlin Heidelberg.

13. Fooddata. Available at: http://frida.fooddata.dk/ ?lang=en

14. SELF Nutrition Data. Available at: http://nutritiondata.self.com/.

15. USDA Food Composition Databases. Available at: https://ndb.nal.usda.gov/ndb/.

16. Khasanov V. I., Ryzhova G. L., Maltseva E. V. Metody issledovaniya antooksidantov [Methods for studying antioxidants]. Khimiya rastitel'nogo syr'ya. 2004, No. 3, P. 63-75 (In Russ.).

17. USDA Database for the oxygen radical absorbance capacity (ORAC) of selected foods, Release 2. Available at: http://www.orac-info-portal.de/download/ ORAC_R2.pdf.

18. Zamknutaya sistema: chelovek-vysshiye rasteniya [Closed system: man - higher plants]. Novosibirsk, Nauka Publ. 1979, 160 p. (In Russ.).

19. Nitta K., Ohya H. Lunar base extension program and closed loop life support systems. Acta Astronautica. 1991, Vol. 23, P. 253-262.

20. Mainous A. G., Wells B. J., Koopman R. J., Everett C. J., Gill J. M. Iron, lipids, and risk of cancer in the Framingham Offspring cohort. American Journal of Epidemiology. 2005, Vol. 161(12), P. 1115-1122.

21. Sullivan J. L. Stored iron and ischemic heart disease: empirical support for a new paradigm (Editorial Comment). Circulation. 1992. Vol. 86, P. 1036-1037.

22. Salonen J. T., Nyyssonen K., Korpela H., Tuomilehto J., Seppanen R., Salonen R. High stored iron levels are associated with excess risk of myocardial infarction in eastern Finnish men. Circulation. 1992, Vol. 86(3), P. 803-811.

23. Agureev A. A., Kalandarov S., Vasilieva V. F., Gurova L. A. [Nutrition of crews of long-term missions on the International Space Station]. Aviakosmicheskaya $i$ ehkologicheskaya medicina. 2004, No. 5, P. 19-23 (In Russ.).

\section{Библиографические ссылки}

1. Olabi A. A. The optimization of a bioregenerative life support space diet // A Dissertation presented to the Faculty of the Graduate School of Cornell University in partial fulfillment of the requirements for the degree of Doctor of Philosophy. 2001.

2. Czupalla M., Horneck G., Blome H. J. The conceptual design of a hybrid life support system based on the evaluation and comparison of terrestrial testbeds // Advances Space Research. 2005. Vol. 35. P. 1609-1620.

3. Protein expression changes caused by spaceflight as measured for 18 Russian cosmonauts / I. M. Larina [et al.] // Scientific Reports. 2017. Vol. 7, Article number: 8142 . 
4. The challenging environment on board the International Space Station affects endothelial cell function by triggering oxidative stress through thioredoxin interacting protein overexpression: The ESA-SPHINX experiment / S. Versari [et al.] // FASEB Journal. 2013. Vol. 27(11). P. 4466-4475.

5. Risk factor of inadequate nutrition: Evidence Report / National Aeronautics and Space Administration ; Lyndon B. Johnson Space Center. Houston, Texas, 2015.

6. Salisbury F. B., Clark M. A. Z. Suggestions for crops grown in controlled ecological life-support systems, based on attractive vegetarian diets // Advances in Space Research. 1996. Vol. 18. P. 33-39.

7. Cooper M., Douglas G., Perchonok M. Developing the NASA food system for long-duration missions // Journal of Food Science. 2011. Vol. 76, No. 2. R40-R48.

8. Quail as a possible object of biological life-support systems of space crews / G. I. Meleshko [et al.] // Acta Veterinaria Brno. 1993. Vol. 62(4). P. 9-15.

9. Closed ecological systems, space life support and Biospherics / M. Nelson [et al.] // Handbook of Environmental Engineering. 2009. Vol. 10. P. 517-565.

10. Gonzales J. M., Paul Jr., Brown B. Nile tilapia Oreochromis niloticus as a food source in advanced life support systems: Initial considerations // Advances in Space Researh. 2006. Vol. 38. P. 1132-1137.

11. SEEF: closed ecology experiment facilities / Ya Tako [et al.] // Gravitational and Space Biology. 2010. Vol. 23. P. 13-23.

12. Mason A. J. OpenSolver - an open source add-in to solve linear and integer progammes in Excel // Operations Research Proceedings / Eds.: Klatte Diethard, Lüthi Hans-Jakob, Schmedders Karl. Springer Berlin Heidelberg, 2012. P. 401-406.

13. Fooddata [Электронный pecypc]. URL: http://frida.fooddata.dk/?lang=en (дата обращения: 10.11.2018).
14. SELF Nutrition Data [Электронный pecypc]. URL: http://nutritiondata.self.com/ (дата обращения: 10.11.2018).

15. USDA Food Composition Databases [Электронный ресурс]. URL: https://ndb.nal.usda.gov/ndb/ (дата обращения: 10.11.2018).

16. Хасанов В. И., Рыжова Г. Л., Мальцева Е. В. Методы исследования антиоксидантов // Химия растительного сырья. 2004. № 3. С. 63-75.

17. USDA Database for the oxygen radical absorbance capacity (ORAC) of selected foods, Release 2 [Электронный pecypc]. URL: http://www.orac-infoportal.de/download/ORAC_R2.pdf (дата обращения: 10.11.2018).

18. Замкнутая система: человек - высшие растения. Новосибирск : Наука, 1979. 160 с.

19. Nitta K., Ohya H. Lunar base extension program $\mathrm{m}$ and closed loop life support systems // Acta Astronaut. 1991. Vol. 23. P. 253-262.

20. Iron, lipids, and risk of cancer in the Framingham Offspring cohort / A. G. Mainous [et al.] // American Journal of Epidemiology. 2005. Vol. 161(12). P. 1115-1122.

21. Sullivan J. L. Stored iron and ischemic heart disease: empirical support for a new paradigm (Editorial Comment) // Circulation. 1992. Vol. 86. P. 1036-1037.

22. High stored iron levels are associated with excess risk of myocardial infarction in eastern Finnish men / J. T. Salonen [et al.] // Circulation. 1992. Vol. 86(3). P. 803-811.

23. Питание экипажей длительных экспедиций на Международной космической станции / А. Н. Агуреев [и др.] // Авиакосмическая и экологическая медицина. 2004. № 5. C. 19-23.

(C) Kovalev V. S., Manukovsky N. S., Tikhomirov A. A., 2018 